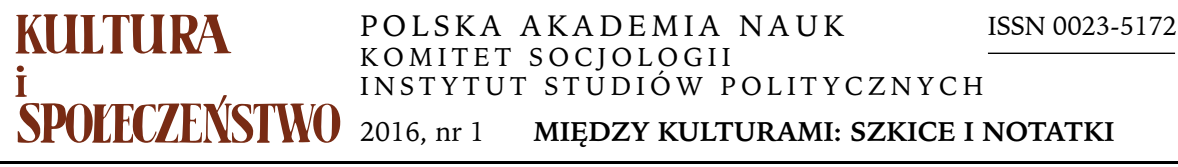

DOMINIKA MIKUCKA-WÓJTOWICZ

Uniwersytet Jagiellonski

\title{
SKORO BAŁKANY ISTNIEJĄ, LEPIEJ ICH NIE WYMYŚLAĆ — MIĘDZY PRAGNIENIEM UCIECZKI DO „EU-ROPY” A „BAŁKANIZACJĄ BAŁKANÓW”*
}

W 1866 roku František Palacky powiedział: „gdyby cesarstwo austriackie nie istniało, należałoby je stworzyć, w interesie Europy, w interesie całej ludzkości" (Škrabec 2013, s. 74), a jego słowa zostały później sparafrazowane przez filozofa Hermanna Keyserlinga, według którego: „Gdyby Bałkany nie istniały, należałoby je wymyślić”. W przypadku Bałkanów jednak można odnieść wrażenie, iż w świadomości ludzi Zachodu w dalszym ciągu dość często istnieją one właśnie jako Bałkany wyobrażone (dzika Europa), pewien fantazmat. Zainteresowanie nimi zaś - na co uczulała Vesna Goldsworthy (2003, s. 369) - zwykle trwa tyle, ile toczące na ich obszarze konflikty. Jednak nawet wówczas jest ono niezwykle powierzchowne, co oznacza, iż Europejczycy nie tyle rzeczywiście chcieliby poznać ich mieszkańców, ile raczej dopasować ich do utrwalonych „popularnych” wyobrażeń (klisz), nacechowanych wyraźną stereotypizacją. Jak zauważył słoweński etnolog i antropolog Božidar Jezernik (2007, s. 17):

„Zachód nigdy nie był przygotowany na to, by ujrzeć Bałkany takimi, jakimi są naprawdę. Zamiast tego poszukiwał cech, które były wyraziste, jednoznaczne i przede wszystkim niezmienne, a takie trudno znaleźć. [...] Zawarte w zachod-

Adres do korespondencji: domiwojt@gazeta.pl

* Artykuł powstał dzięki wsparciu finansowemu Uniwersytetu Jagiellońskiego w ramach programu SET (Interdyscyplinarne Studia Doktoranckie „Społeczeństwo - Technologie — Środowisko"), który współfinansuje Unia Europejska. Wstępna wersja rozważań została zaprezentowana w referacie wygłoszonym podczas międzynarodowej konferencji naukowej: „Narody i stereotypy 25 lat później. Nowe granice, nowe horyzonty", zorganizowanej przez Międzynarodowe Centrum Kultury w Krakowie w dniach 4-6 czerwca 2014 r. 
nich relacjach obrazy mieszkańców Bałkanów nie były w pierwszym rzędzie, o ile były w ogóle, opisami prawdziwych ludzi, lecz raczej projekcjami własnej nostalgii i poczucia niższości. Przy czym im bardziej starano się zgłębić ten temat $z$ różnych perspektyw, tym bardziej obraz Bałkanów stawał się zamazany".

Jednocześnie Bałkany są przez nich postrzegane $z$ jednej strony jako beczka prochu, region skażony „odwieczną” nienawiścią zamieszkujących go narodów i splamiony krwią ich bratobójczych walk; w najlepszym wypadku zaś stanowią synonim skrajnego uwstecznienia i obskurantyzmu, z którego może je wydobyć jedynie europejski paternalizm (stereotyp ów określam umownie mianem „Bałkanów drastycznych”). Z drugiej — „jaśniejszej” (nazwanej przeze mnie stereotypem „Bałkanów magicznych”), jawią się niemal jako ludyczny skansen, rodem z filmów Emira Kusturicy, czy - w nieco uwspółcześnionej wersji - kraina pełna szalonych imprez i równie „szalonych lasek", jak wyśpiewuje Neda Ukraden, nieco przaśnego festiwalu w Gučy czy doskonałego miejsca na "safari” dla zachodnich globtroterów (Jansen 2001, s. 61-62; Luketić 2008, s. 20). Ci, którym bliższe jest pierwsze spojrzenie, marzą o ucieczce z Bałkanów do „EU-ropy” (choć Europa niekoniecznie czeka na nich $z$ otwartymi ramionami), drudzy zaś $w$ zasadzie nie mają nic przeciw, aby pozostać $\mathrm{w}$ tej idyllicznej, płynącej rakiją krainie. Co więcej, często wręcz podtrzymują ów stereotyp poprzez wykorzystanie strategii „samobałkanizacji", rozumianej przeze mnie nie jako rozdrobnienie, lecz specyficzna wersja „samoorientalizacji”/,samouegzotycznienia” (por. Todorova 2008, s. 19, 79). Celem rozważań jest przybliżenie genezy i sposobu funkcjonowania wyżej wspomnianych stereotypów oraz analiza związanego z nimi dyskursu (rozumianego jako ramy myślenia występujące $\mathrm{w}$ poszczególnych dziedzinach życia społecznego) w dwóch, z pozoru bardzo odległych od siebie, wymiarach życia społecznego - polityki oraz sztuki. Głos w dyskusji — w duchu teorii postkolonialnej $^{1}$ - chciałabym oddać nie tylko przedstawicielom Zachodu, ale też - a nawet przede wszystkim - mieszkańcom Bałkanów, czyli jakby powiedziała Gayatri Chakravorty Spivak (1988) „rdzennym (rodzimym) informatorom".

\footnotetext{
${ }^{1}$ Maria Todorova podnosiła, iż Bałkany nigdy nie były kolonią sensu stricto, w takim sensie jak państwa Afryki czy Ameryki Południowej. Jednak — jak zauważył jeden z ojców orientalizmu Edward Said, kolonie muszą być niekoniecznie tworem geopolitycznym, ale przede wszystkim mentalnym i dyskursywnym, opartym na kulturowej represji. Choć inność Wschodu budzi fascynację Zachodu, najczęstszym modelem jej podporządkowania/ujarzmienia jest próba narzucenia swojej tożsamości, a więc próba utworzenia ze Wschodu wiernej kopii Zachodu (carbone copy). Jednak $z$ uwagi na fasadowość choćby $w$ naśladowaniu zachodnich instytucji kolonie często stawały nie tyle jego kopią, ile karykaturą. Pisanie zaś o Wschodzie w rzeczywistości polegało na tworzeniu projekcji - ideologicznych konstrukcji myślowych — dotyczących Wschodu, które więcej mówiły o kryjących się za zastosowanym dyskursem zachodnich mechanizmach władzy i opresji niż o przedmiocie opisu (zob. Said 1991; Wallerstein 2007, s. 50-51; Buden 2011; Jezernik 2007, s. 240; Oczko 2007, s. 250).
} 


\section{GDZIE LEŻĄ BAŁKANY}

Termin „Bałkany” upowszechnił się dopiero w XIX wieki i oznaczał wówczas pasmo górskie oddzielające ówczesną Bułgarię od Rumunii, wcześniej określane jako Haemus-Hajmos. Według ówczesnego angielskiego podróżnika Johna Moritta, który jako jeden z pierwszych wspomniał nową nazwę, określenie „Bal Kan” było poniżające dla masywu, niegodne poprzedniego miana (wręcz degradowało jego znaczenie) (Todorova 2008, s. 58; Jezernik 2007, s. 13). W języku tureckim, z którego się wywodzi ów toponim, nazwa balkan oznacza urwistą i gęsto zalesiona górę lub łańcuch górski. Jednak później tłumaczono ją jako połączenie słów bal (miód) i kan (krew). Nazwa Bałkany odnosiła się więc do wyżynno-górskiego obszaru obecnie raczej nazywanego Starą Płaniną (Markowska 2010, s. 47). Z kolei „ojcem” terminu „Półwysep Bałkański" jest niemiecki geograf August Zeune (pierwszy raz użył go w 1808 roku), co wiązało się z powszechną praktyką nazywania terenów od znaczących łańcuchów górskich. Jednak współcześnie jego wybór uznawany jest za dość przypadkowy (Jezernik 2007, s. 13).

$\mathrm{Z}$ uwagi na fakt, iż granice między półwyspem a resztą Europy od początku były dość umowne (Slukan-Altić 2011, s. 402-405), do dziś wielu trudności nastręcza zdefiniowanie jego mieszkańców. Miroslav Krleža, jeden z najwybitniejszych chorwackich pisarzy XX wieku, jako granicę cywilizacyjną Europy wskazał taras hotelu Esplanada, mieszczącego się tuż obok dworca kolejowego z Zagrzebiu, za którym rozpoczynało się bałkańskie błoto" (zob. Rihtman-Auguštin 1997, s. 32). Nieco odmiennie tę kwestię postrzega serbski antropolog Marko Živković, dla którego umowną linię delimitacyjną Bałkanów wyznacza granica zasięgu występowania kawy parzonej po turecku (turska kafa). Jak zauważa: fakt, czy pije się kawę po wiedeńsku (czyli kawę udekorowaną bitą śmietana) czy też kawę parzoną po turecku (w tygielku/dżezwie), ma poważne geopolityczne skutki (Živković 2012, s. 70). Oczywiście „Bałkańczyk” może próbować się ukryć zamawiając kawę po wiedeńsku, jednak dość łatwo może go zdekonspirować zanurzenie w niej rogalika, gdyż — według jednej z bohaterek Krleży — tak robią tylko „bałkańscy Cyganie” (Rihtman-Auguštin 1997, s. 33). Z kolei pytany o kwestię granic słoweński filozof Slavoj Žižek odpowiedział:

„Pomyślmy o Bałkanach. Zachodnie media ukazują je jako kłębowisko etnicznych namiętności - koszmar śniony przez fana wielokulturowości. Typowa reakcja Słoweńca (takiego jak ja) to: «tak właśnie jest na Bałkanach, ale Słowenia do nich nie należy, Słowenia to Mitteleuropa; Bałkany zaczynają się w Chorwacji albo Bośni; my Słoweńcy jesteśmy przedmurzem europejskiej cywilizacji chroniącym ją przed bałkańskim szaleństwem». Dla Serbów Bałkany zaczynają się w Kosowie albo w Sarajewie, gdzie Serbia broni cywilizowanej chrześcijańskiej Europy przed Innym. Dla Chorwatów Bałkany to ortodoksyjna, bizantyjska Serbia, przeciwko której Chorwacja broni wartości zachodniej demokracji. Dla wielu Włochów i Austriaków Bałkany zaczynają się w Słowenii, tym zachodnim 
przyczółku słowiańskich hord. Wielu Niemcom Austria kojarzy się z bałkańską korupcją i brakiem skuteczności; zdaniem Niemców z Północy, katolicka Bawaria nie jest wolna od bałkańskiej zarazy. Niektórzy aroganccy Francuzi kojarzą Niemców ze wschodniobałkańską brutalnością. W końcu, brytyjscy przeciwnicy Unii Europejskiej postrzegają kontynentalną Europę jako nową wersję tureckiego imperium z Brukselą jako nowym Istambułem, zagrażającym brytyjskiej wolności i suwerenności" (Zižek 1999; cyt. za: Pabijanek 2010).

Rekapitulując można też zastosować znaną lapidarną maksymę innego słoweńskiego badacza Rastka Močnika: „Bałkany to są inni” (Balkan, to su drugi). Zjawisko to zauważyła i zdefiniowała na początku lat dziewięćdziesiątych XX wieku mająca jugosłowiańskie korzenie badaczka Milica Bakić-Hayden (1995, s. 918, 922), która określiła je mianem „zagnieżdżonego orientalizmu”. Według niej, jego zastosowanie służy do wytworzenia pewnej wewnętrznej hierarchii (wewnętrznego zróżnicowania) wśród mieszkańców regionu. Dobrym przykładem potwierdzającym jej spostrzeżenia są wnioski płynące $z$ eskapady odbytej w 2009 roku przez dziennikarzy splickiego dziennika „Slobodna Dalmacija" (Balkanski... 2009), podczas której badano percepcję Bałkanów wśród ich rodzimych mieszkańców - intelektualistów z Czarnogóry, Kosowa, Macedonii, Grecji oraz Serbii. Co warte uwagi, przedstawiciele różnych państw zaliczanych do grona bałkańskich często mieli dość odmienne zdania co do granic regionu, a także samej klasyfikacji ich kraju. Czarnogórscy pisarze Jevrem i Balša Brković - podkreślali na przykład, że Bałkany są sztucznym tworem, czego według nich dowodzi fakt, iż nazwa ta nie występuje w klasycznym czarnogórskim poemacie Górski wieniec dziewiętnastowiecznego wieszcza i władyki Petara II Petrovicia Njegoša. Sama Czarnogóra zaś jest państwem śródziemnomorskim. Choć z drugiej strony grecki poeta Emanuel Rassoulis — w duchu przemyśleń Amina Maaloufa (2002) — podkreślał, iż państwa czy ludzie w naturalny sposób mogą łączyć wiele tożsamości, w przypadku Grecji śródziemnomorską i bałkańską. Wiele problemów sprawiły też próby klasyfikacji Chorwacji. Według większości rozmówców do Bałkanów zdecydowanie nie należy Istria i północna Chorwacja, podobnie jak Słowenia, nigdy bowiem nie wchodziły one w skład imperium osmańskiego. Choć dla odmiany macedoński muzyk Vlatko Stefanovski i grecki działacz kulturalny Nikos Stefanidis za bałkańskie miasto uznali Wiedeń, po którym kręci się tyle naszych ludzi (mota toliko naših ljudi) (Balkanski... 2009).

\section{JAK TO MOŻLIWE, ABY KTOŚ BYŁ BAŁKAŃCZYKIEM?}

Podobny okrzyk zdziwienia jak ten wspominany przez Rikę - jednego $z$ bohaterów Listów perskich wydanych anonimowo przez Monteskiusza - wydawany przez mieszkańców Paryża na wieść, że jest on Persem, równie dobrze mógłby się odnosić do mieszkańców Bałkanów (Montesquieu 1979, s. 68-69; por. Wallerstein 2007, s. 46). Ważnym pytaniem w tym kontekście jest: skąd 
się bierze niechęć do klasyfikowania się, a jeszcze gorzej bycia postrzeganym przez innych jako „Bałkańczyk”. W zasadzie jest to więc pytanie o przyczyny stygmatyzacji Bałkanów, rozumianej jako upowszechnienie się negatywnych stereotypów ${ }^{2}$, funkcjonujących na wszystkich trzech poziomach (czyli tzw. auto-, hetero- oraz metastereotypów).

Jak zaznaczyłam na wstępie, w przypadku Bałkanów możemy mówić, oczywiście nie unikając przy tym generalizacji, o dwóch wyjątkowo żywotnych stereotypach, nazwanych przeze mnie umownie: „Bałkanami magicznymi” i „Bałkanami drastycznymi”. Pierwszy z nich jest nieco starszy, właściwie można go więc traktować jako pierwotny. Według Todorovej niemal do końca XIX wieku w relacjach podróżników dominowała fascynacja odkrywaniem tego regionu. Bałkany były postrzegane jako swoista ostoja tradycji, skansen dawnego świata, odbicie Europy z „odległej” przeszłości, miejsce wypełnione nieco magiczną, na poły orientalną mistyką, które choć nie było Orientem, jednak „odbijało jego światło". Udający się tam mieszkańcy Zachodu oczekiwali, że zobaczą dziewiczą przyrodę i spotkają "malowniczy, interesujący lud” (Todorova 2008, s. 42, 45). W ich oczach stanowiły one wspaniały przykład „egzotycznej bliskości” (Luketić 2013, s. 56), a przekazywane przez nich nieraz dość niewiarygodne historie, na przykład o sposobie Czarnogórców na leczenie migreny przez „wiercenie sobie dziur w głowie przy każdym ataku bólu” (Bogusławska 2008, s. 232), mogły fascynować tym, że odbywają się w miejscach jawiących się jako $z$ jednej strony całkowicie nieeuropejskie, a $z$ drugiej niezwykle bliskie Europie (Luketić 2013, s. 56). To znaczy bliskie geograficznie, lecz odległe kulturowo. Dla pełnego obrazu sytuacji należy dodać, iż już we wczesnych relacjach ta fascynacja nie była oczywiście pozbawiona śladów postawy nazwanej przez Tzvetana Todorova mianem „ksenofilii ludzi Zachodu”, cechującej się życzliwym odbieraniem innej kultury, której jednakże a priori przypisuje się niższą wartość (cyt. za: Todorova 2008, s. 137). Ponadto, co podkreśla Todorova (2008, s. 42, 45), od nieco efemerycznego, uromantycznionego przez pisarzy Orientu odróżniał je fakt, że były bardziej prozaiczne, „przyziemnie konkretne i niemal pozbawione bogactwa, a pokrywająca je warstwa cywilizacji często okazywała się powierzchowna".

Współczesna, ludyczna wersja tego stereotypu często, jak w przypadku filmów Kusturicy, bywa wynikiem świadomego uegzotycznienia czy „komercjalizacji bałkańskiej samoorientalizacji", dokonywanej w celu wpisania się w zachodnie klisze i wyobrażenia (zob. Kršić 2003; Iordanova 2010, s. 56; por. Matošević 2011, s. 33). Z jednej strony miało to utwierdzić zachodnich odbiorców

\footnotetext{
$2 \mathrm{~W}$ znaczeniu lippamanowskich „obrazów w naszych głowach” czy jezernikowskich „kolektywnych konstrukcji”, pozyskiwanych przez jednostki w procesie kontaktów społecznych, a nie W wyniku obserwacji rzeczywistości. W psychologii społecznej stereotypy uchodzą za produkt „poznawczego skąpstwa”, gdyż powstają w wyniku prób ograniczenia nadmiaru informacji (Fiske, Taylor 1984; zob. Piber-Dąbrowska, Sędek 2006, s. 7).
} 
w słuszności ich osądów. Z drugiej zaś podsycić ich fascynację tym „dzikim” regionem. Według Diny Iordanovej $(1996$, s. 883, 888), była to strategia niezwykle sprytna, pomagała bowiem twórcom - świadomym marginalności ich kultury - zrobić z tego zaletę. Należy dodać, iż podtrzymywanie czy podsycanie takich stereotypów znajduje przeciwników zarówno wśród zewnętrznych, jak i wewnętrznych odbiorców. Do najbardziej zaciekłych krytyków twórczości Emira Kusturicy należą macedońska literaturoznawczyni Elizabeta Šeleva oraz słoweński filozof Slavoj Žižek. Oboje wielokrotnie podkreślali, iż stosowana przez niego strategia przynosi dużo szkody, gdyż reżyser w pełni przyswoił sobie zachodnie wyobrażenia o Bałkanach jako o „dzikiej Europie”. Kusturica odrzucał te zarzuty i twierdził, że celem, który przyświecał mu w czasie prac nad filmem Underground - dziś mającym status kultowego i nagradzanym na zachodnich festiwalach - było „pokazanie mentalności naszych ludzi” (Matošević 2011, s. 40). Jednak według Žižka, o czym wspomina on między innymi w filmie Hermanna Vaske Batkańska dusza, rzeczywiste życie Serbów dalekie jest od jego wizji zaprezentowanej w tym obrazie, z którego można wnioskować, iż upływa im ono wyłącznie na ciągłym jedzeniu, piciu, śpiewaniu, uprawianiu seksu i zabijaniu. Šeleva dodawała do tego jeszcze historię opowiedzianą w jednym w wywiadów przez innego serbskiego reżysera - Srđana Karanovicia, który żalił się, iż ciężko mu zdobyć pieniądze od zagranicznych producentów, gdyż są oni gotowi zainwestować jedynie w produkcje, w których wykorzystywana jest „bałkańska mieszanka krwi, przemocy, wojny, namiętności”, a więc bardzo zredukowana (esencjalistyczna) wizja tego regionu, wpisująca się w stylistkę gonzo (Luketić 2008b, s. 27; Szczerek 2013, s. 99).

Później, od końca XIX wieku, czyli od czasu gdy na Bałkanach powoli zaczynają się kształtować państwa narodowe na wzór europejski, jednocześnie przybiera na sile proces ich stygmatyzacji. Jak podkreśla Žižek (2009a, s. 291): „Rozziew między tym, jak postrzegane były wcześniej przez Zachodnią Europę, a ich "nowoczesnym» wizerunkiem jest doprawdy uderzający". Bardzo ważnym, wręcz przełomowym okresem, w umocnieniu się tego stereotypu było pierwszych czternaście lat XX wieku, kiedy to w 1903 roku w Belgradzie dokonano zamachu na ówczesnego króla Aleksandra Obrenovicia i jego żonę, a ich ciała wyrzucono przez okno pałacu, co wzbudziło przerażenie w Europie Zachodniej, następnie toczące się w latach 1912-1913 wojny bałkańskie (przy czym o ile jeszcze pierwszą idealizowano i patrzono na nią jak na romantyczny, niepodległościowy zryw mający na celu obalenie władzy imperium osmańskiego, o tyle w przypadku drugiej mówiono już o bratobójczych walkach powodowanych odwieczną nienawiścia), a w końcu także dokonany rok później przez Serba Gavrilo Principa zamach na arcyksięcia Ferdynada w Sarajewie, od którego rozpoczęła się pierwsza wojna światowa. Wówczas Bałkanom zaczęto przypisywać nie tylko cechy dotychczas postrzegane jako orientalne, co przywoływało skojarzenia z brudem, biernością, niesolidarnością, mizoginią, skłonnością do intryg, lenistwem, wiarą w przesądy, ale też stereotyp wzbo- 
gacono o nowe cechy, takie jak okrucieństwo, chamstwo, nieprzewidywalność (Todorova 2008, s. 258). Z czasem coraz częściej postrzegano Bałkany jako bardziej zacofanego Innego Europy ${ }^{3}$ (ta nieco bardziej łagodna w swojej wymowie etykieta coraz częściej była zarezerwowana dla państw Europy Wschodniej), ale przede wszystkim gorszego, owładniętego niezrozumiałą dla Zachodu przemocą (wręcz biologiczną skłonnością do przemocy), którego „dzikość”, dotychczas postrzegana jako fascynująca, zaczęła budzić przerażenie i odrazę (Bakić-Hayden 1995, s. 917). Angielska podróżniczka Mary Edith Durham po wybuchu pierwszej wojny światowej oskarżała Serbów, że są winni największej zbrodni w historii ludzkości (Todorova 2008, s. 259). Wśród ówczesnych zagranicznych podróżników i dziennikarzy relacjonujących przebieg wojen bałkańskich powszechne było przekonanie, że taka eskalacja przemocy nie mogłaby się zdarzyć na Zachodzie. I choć wkrótce, wraz z wybuchem pierwszej, a później drugiej wojny światowej, ich niezachwiana pewność została wystawiona na poważną próbę, nie wszyscy zachodni globtroterzy odrzucili dawne przekonania. W wydanej w 1993 roku książce Bałkańskie upiory. Podróż przez historię amerykański dziennikarz Robert Kaplan roztoczył bardzo sugestywną wizję rzekomo bałkańskich korzeni nazizmu: „To przecież $\mathrm{w}$ dzielnicy wiedeńskich noclegowni, wylęgarni etnicznych resentymentów, nieopodal granicy południowej Słowiańszczyzny Hitler nauczył się tak zaraźliwie nienawidzić" (Kaplan 2010, s. 26). Tę nieuzasadnioną ocenę można by zbyć milczeniem, gdyby nie fakt, iż istnieje przeświadczenie, iż właśnie jej lektura zniechęciła prezydenta Billa Clintona do wcześniejszej interwencji w Bośni.

Oczywiście zaprezentowana w dużym skrócie wizja stereotypów dotyczących Bałkanów, którą umownie możemy nazwać zachodnią, jest nazbyt esencjalistyczna. Nawet jeśli mówiąc o Bałkanach weźmiemy pod uwagę tylko mieszkańców byłej Jugosławii - a tak często się działo, po tym jak wojny związane $z$ dezintegracją państwa federalnego nazbyt bezrefleksyjnie okrzyknięto mianem bałkańskich - trzeba pamiętać, że w obrębie samego jugosłowiańskiego imaginarium funkcjonowało wiele heterostereotypów o zamieszkujących go narodach i narodowościach. Jako komentarz mogą posłużyć słowa chorwackiej pisarki Dubravki Ugrešić (2008, s. 30-31):

„Dorosłam w kraju, w którym braterstwa i jedności pilnowano jak źrenicy oka swego, jednocześnie jednak pielęgnowano stereotypy o członkach tego bractwa. Żyłam otoczona Słoweńcami, którzy byli skąpi, Słowenkami, które spośród wszystkich członkiń bractwa najchętniej zadzierały spódnice, Czarnogórcami, którzy byli leniwi, Chorwatami, którzy byli namolni jak wesz i do tego pe-

\footnotetext{
3 Po drugiej wojnie światowej europejskość państw Europy Środkowo-Wschodniej i Półwyspu Bałkańskiego była podawana w coraz większą wątpliwość, a granice Unii Europejskiej zaczęły pełnić rolę swoistych granic cywilizacyjnych. Wymownym tego przykładem jest fakt, że gdy w latach dziewięćdziesiątych zaczęto nieśmiało wspominać o możliwości przyszłej akcesji Słowenii czy Polski do UE, mówiono „wprost i bez zażenowania”, że w ten sposób „przyłączy się je do Europy” (Judt 2012, s. 9).
} 
dałami, Serbami, którzy byli prymitywnymi wsiokami, tępakami, Macedończykami, którzy byli najgorszymi z prowincjuszy, Bośniakami, którzy byli głupi, Albańczykami, którzy właściwie nie byli ludźmi, Muzułmanami, którzy zamiast pięciu mieli po sześć palców u nóg, mniejszościowymi Włochami, którzy jedli koty i wspomnianymi już Cyganami, którzy kradną dzieci. Wziąwszy to wszystko pod uwagę, żyłam w wyjątkowo interesującym otoczeniu. Wyjeżdżając z kraju, myślałam, że porzucam zonę stereotypów. Pomyliłam się, stereotypy wokół mnie się rozmnożyły. [...] W zjednoczonej Europie naprawdę czuję się jak w domu. Co więcej, stereotypy są ideologiczną i komercyjną etykietą Unii Europejskiej".

\section{BAŁKANY W DYSKURSIE POLITYCZNYM}

Przede wszystkim interesuje mnie nie tyle dyskurs, który został „zmaterializowany" w dokumentach politycznych, ile raczej dyskurs polityków dotyczący tego regionu, i to zarówno jego mieszkańców, a więc „rdzennych informatorów", jak i reprezentantów tzw. zakorzenionych demokracji. Zgodnie z przywoływanym już spostrzeżeniem Vesny Goldsworthy, nie dziwi, iż zainteresowanie Bałkanami przeżywało renesans w latach dziewięćdziesiątych, kiedy toczyły się konflikty związane z rozpadem państwa federalnego - SFRJ. Przy czym zostały one okrzyknięte, zupełnie nieadekwatnie do ich przyczyn i zasięgu, mianem wojen bałkańskich, co według niektórych badaczy miało na celu ich odpolitycznienie, ale też zdjęcie z państw Zachodu jakiejkolwiek odpowiedzialności za ich wybuch i przebieg (Avgita 2007, s. 219). Obraz wyłaniający się z ówczesnych relacji zagranicznych polityków i dziennikarzy to wizja Bałkanów jako:

„[...] swoistego domu wariatów, w którym kwitną nacjonalizmy, i gdzie zawieszone są racjonalne reguły zachowania. [...] miejsca dzikich konfliktów, które cywilizowana Europa już dawno przezwyciężyła; miejsca, gdzie nic nie zostaje zapomniane i z niczego nie wyciąga się lekcji, gdzie stare traumy odgrywa się po raz kolejny i kolejny; miejsca, gdzie więź symboliczna jest zarazem niedoceniana (zrywa się dziesiątki zawieszeń broni) i przeceniana (prymitywne poglądy na temat honoru i dumy wojowników). [...] w kryzysie jugosłowiańskim: w tych «konfliktach etnicznych» nie ma nic autochtonicznego. Zachodnie spojrzenie było w nie włączone od początku — Dawid Owen i spółka są dzisiejszą wersją tej ekspedycji badającej nowozelandzkie plemię" (Žižek 2009b, s. 453-454).

Głos „rodzimych informatorów” był słabo słyszalny w tej dyskusji, po części z uwagi na fakt, iż kwestionowano ich obiektywizm. Po drugie, ich analizy często koncentrowały się na problemie niewydolności modelu społeczno-gospodarczego przyjętego w Jugosławii po drugiej wojnie światowej, które były tyleż bardziej zawiłe, co mniej medialne (Goldsworthy 2003, s. 372). Po trzecie zaś, zwykle ich relacje były pisane w ojczystych, słowiańskich językach, co ograniczało możliwości ich recepcji. Žižek jest tu jednym z nielicznych wyjątków. Warto zaznaczyć, że przez swoją pracę naukową byli oni związani z zagranicz- 
nymi uniwersytetami (podobnie jak dwie najsłynniejsze badaczki zajmujące się tym regionem, również mające słowiańskie korzenie: Maria Todorova i Milica Bakić-Hayden oraz większość badaczy specjalizujących się w problematyce postkolonializmu). Do masowej świadomości przebijali się przede wszystkim zagraniczni autorzy, zafascynowani „wojenną egzotyką" (Luketić 2008a, s. 22), którzy według Todorovej (2008, s. 53) uprawiali tzw. dziennikarstwo akademickie. Liczba przykładów takich analiz jest naprawdę imponująca. Brytyjski pułkownik Bob Stewart, autor książki poświęconej konfliktowi w Bośni, przekonywał, że relacje zamieszkujących ją narodów (Serbów, Chorwatów i Muzułmanów) od wieków były straszne. Dlatego też nie dziwi, iż jego rodak Misha Glenny (dziennikarz, autor książki o historii Bałkanów; 2012) posunął się nawet krok dalej i dla zobrazowania wzajemnych stosunków etnicznych posługiwał się obrazową metaforą wampiryzmu. Według niego, zamieszkujące ten region narody muszą co jakiś czas upuścić sobie nawzajem trochę krwi, aby uwolnić się od ucisków odwiecznych nienawiści. Z kolei brytyjski dziennikarz Michael Nicholson dodawał jeszcze, iż bezprecedensowa gwałtowność (i prymitywizm) bałkańskich narodów sprawia, iż antropolodzy porównują je do prymitywnych plemion amazońskich (Goldsworthy 2003, s. 366-368). Ich opinie świetnie puentuje stwierdzenie Richarda Holbrooke'a, jednego z ówczesnych autorytetów w kwestii tego regionu, który powiedział, że wprawdzie „koncepcja o „pradawnych nienawiściach” jest niejasna”, jednakże jest zarazem przydatna do opisania „historii zbyt skomplikowanej (lub trywialnej), aby mogli ją opanować ludzie z zewnątrz [outsiderzy]" (Holbrooke 1999, s. 22). Jednak, jak słusznie zauważyła Goldsworthy (2003, s. 368), upowszechnienie takich metaforycznych wizji Bałkanów jako beczki prochu w połączeniu z dominującym wówczas i upowszechnianym przeświadczeniem o „odwiecznej nienawiści" między zamieszkującymi je narodami przede wszystkim dawało zachodnim państwom wygodną wymówkę do zrzucenia $z$ siebie jakiejkolwiek odpowiedzialności za ówczesną eskalację konfliktów i spychało w cień kwestię ich interesów związanych z tym regionem.

Dokonywana przez zachodnich „specjalistów” irracjonalna interpretacja konfliktu, skutkująca wzmożoną stygmatyzacją Bałkanów, powodowała, że niektóre państwa postjugosłowiańskie, zwłaszcza Słowenia i Chorwacja, od początku lat dziewięćdziesiątych próbowały kwestionować swoje związki $\mathrm{z}$ tym regionem. Słoweńscy komuniści już w pierwszych wolnych wyborach w 1990 roku prowadzili kampanię pod hasłem „Europa teraz”, a ubiegający się o reelekcję w 1995 roku chorwacki prezydent Franjo Tuđman walczył o mandat pod hasłem: „Tuđman nie Bałkany”. W dwa lata później ów prezydent był inspiratorem nowelizacji konstytucji, której celem było wprowadzenie przepisu zabraniającego Chorwacji stowarzyszania się z innymi bałkańskimi państwami, co mogłoby doprowadzić do odnowienia federacji jugosłowiańskiej. Podejmowane przez ówczesne elity próby zerwania czy też zakwestionowania więzi z Bałkanami często były groteskowe w swojej zapalczywości, a ich efekt 
całkowicie odwrotny od zamierzonego. Albowiem im bardziej gorączkowo próbowały one uciec od Bałkanów, tym mocniej podkreślały swoją przynależność do nich.

Aby zdestygmatyzować Bałkany, w drugiej połowie lat dziewięćdziesiątych zaczęto używać terminu Europa Południowo-Wschodnia. Według chorwackich źródeł obejmowała ona Albanię, Bośnię i Hercegowinę, Bułgarię, Czarnogórę, Macedonię, Rumunię, Serbię; niekiedy także rozszerzano to pojęcie na: Grecję, Mołdawię, Słowenię, Chorwację, a nawet wschodnią Trację. Według źródeł zachodnich ograniczała się ona do byłej Jugosławii, ale bez Słowenii, za to z Albanią. Jednak termin ów miał krótką żywotność. W 2003 roku niemal ostatecznie został wyparty przez określenie Bałkany Zachodnie (Western Balkans) ${ }^{4}$, które słoweński badacz Mitja Velikonja przez analogię do popularnej w tym regionie muzyki turbo folk, nazywanej też nowo komponowaną muzyką, nazywa „nowo komponowanym terminem" (Velikonja 2007, s. 6). Oba przywołane powyżej toponimy możemy za Gordaną Đerić (2009, s. 16) traktować jako przejawy „strategii destygmatyzacyjnej” czy próbę „debałkanizacji Bałkanów”, w znaczeniu ich westernizacji. Choć - jak podkreśla Predrag Svilar (2010, s. 534), jeden z serbskich badaczy zajmujący się medialnym dyskursem dotyczącym Bałkanów Zachodnich - „Bałkany Zachodnie w stosunku do Zachodu zawsze pozostaną Wschodem". Ponadto wśród państw klasyfikowanych do tego regionu istnieje przeświadczenie, iż termin ten będzie istnieć dopóki nie zakończy się proces ich integracji z UE. Sama nazwa zaś łączy w sobie elementy przysłowiowej strategii kija i marchewki: albo się dostosujecie i w nagrodę przyłączycie się do Zachodu, albo wrócicie na Bałkany. Jednak trzeba mieć na uwadze, że tworząc ją próbowano zmienić ich wizerunek nie tylko wśród rodzimych mieszkańców, ale też w oczach obywateli państw Unii, którzy niekoniecznie byli przychylni integracji Bałkanów z UE, z uwagi na wcześniejszą wieloletnią stygmatyzację regionu.

Javier Solana (były wysoki przedstawiciel UE ds. wspólnej polityki zagranicznej i bezpieczeństwa) powiedział: „Bałkany Zachodnie to nie jest nic innego jak pewien eksperyment, od którego zależy przyszłość Europy”. Jednak komentując jego słowa chorwacki politolog Anđelko Milardović (2000) stwierdził, że dzięki tej koncepcji zepchnięto Chorwację oraz inne państwa postjugosłowiańskie do trzeciej ligi. Predrag Svilar, który zajmował się analizą języka mediów i polityków, zauważył, iż stosowanie tego terminu w różnych państwach różni się pod względem częstotliwości i odcienia semantycznego. W 2009 roku, kiedy według jego obliczeń owych referencji było najwięcej, ich liczba, jeśli porównamy macedoński dziennik „Dnevnik”, portal serbskiej rozgłośni B92 i chorwacki dziennik "Jutarnji list”, wynosiła odpowiednio: 1430, 706 i 115. Przy czym w chorwackiej prasie miały one zwykle negatywne konotacje, gdyż Chorwaci uważali, że Unia spycha ich państwo na Bałkany (Svilar 2010, s. 524,

4 Po raz pierwszy zostało ono zapisane w przyjętym w 2003 roku dokumencie „Agenda z Salonik dla Bałkanów Zachodnich". 
526, 531). W chorwackim dyskursie medialnym w okresie prowadzenia przez Chorwację negocjacji akcesyjnych raczej mówiło się o państwach Bałkanów Zachodnich i Chorwacji albo o „państwach regionu”, unikając jakiegokolwiek odwołania do nazwy Bałkany, będącej symbolem przestrzeni, z której Chorwaci za wszelką cenę chcą się wydostać, a za żadną nie chcą być z nią utożsamiani. Chorwacki premier Ivo Sanader (2009), choć wcześniej podkreślał, że „nie trzeba się obciążać terminem Bałkanów Zachodnich”, jednak wyjaśniając w 2009 roku przyczyny podania się do dymisji, tłumaczył: że na jego decyzję wpłynęła słoweńska blokada negocjacji akcesyjnych Chorwacji, która była spowodowana „słoweńskim, bałkańskim prowincjonalnym nacjonalizmem” (zob. Svilar 2010, s. 512). Z kolei publicystka Jelena Lovrić (2008), komentując zapowiedź startu w wyborach prezydenckich w Chorwacji w 2009 roku Miroslava Tuđmana (syna byłego prezydenta Franja Tuđmana), stwierdziła: „jeśli wzniecanie strachu przed Bałkanami Zachodnimi ma być głównym punktem platformy programowej, z którą rusza on do wyborczego wyścigu, to będzie to taniec wampirów".

Mimo deklaracji „EU-ropejskiej” przyszłości dla państw Bałkanów Zachodnich, czego przykładem może być obietnica Tony’ego Blaira: „nie skończymy pracy na Bałkanach, dopóki wszystkie państwa Bałkanów Zachodnich nie będą całkowicie zintegrowane z Unią" (Svilar 2010, s. 515), Unia nie czekała i nie czeka na nie $z$ otwartymi ramionami. Unijna administracja forsuje - przynajmniej na poziomie deklaratywnym, bo poszczególne państwa spełniają te wymogi z różnym skutkiem - strategię nazywaną przez postkolonialistów mianem „klonowania” bądź „wiernej kopii”, czyli integrację przebiegającą w myśl zasady: „Macie się do nas upodobnić”. Dlatego też nie dziwią wypowiedzi takie jak Miroslava Lajčaka (ówczesnego szefa dyplomacji Słowacji, a wcześniej wysokiego przedstawiciela ONZ w Bośni), który komentując w 2009 roku europejskie aspiracje państw $\mathrm{w}$ regionu Bałkanów Zachodnich stwierdził: „[...] nie są jeszcze wystarczająco dojrzałe do integracji, ale muszą wiedzieć, że myślimy o nich poważnie i taka perspektywa z pewnością się dla nich otworzy, gdy do tego dorosną" (Petrović 2012, s. 47). Z kolei jego austriacka odpowiedniczka, minister Ursulla Plassnik, w 2008 roku upominała Chorwatów, że aby wejść do Unii, najpierw muszą dokończyć odrabianie zadanej im pracy domowej (Plassnik... 2008). Użycie takich metafor ma duży ciężar symboliczny, gdyż — co podkreśla Boris Buden (2012, s. 33) — „żadna relacja władzy nie jest równie niewinna i uzasadniona niż ta nad niedojrzałymi dziećmi". Co warte odnotowania, po akcesji do UE ów paternalistyczny dyskurs był przejmowany przez kolejne państwa regionu (Słowenię, a później Chorwację). Stosowaną przez nie strategię można umownie określić mianem „reprodukcji imperializmu”, po akcesji zaczynały one bowiem odgrywać imperialną rolę wobec „infantylizowanych" dawnych sąsiadów z jugosłowiańskiego federalnego państwa, którzy dopiero aspirują do członkostwa.

Można zaryzykować twierdzenie, iż żądając dostosowania, Unia kieruje się pragnieniem ujrzenia „zreformowanego, rozpoznawalnego Innego, jako pod- 
miotu różnicy, który jest prawie taki sam, ale nie całkiem" (Bhabha 2010, s. 80), co przez Homi Bhabhę zostało określone mianem „mimikry kolonialnej”. Pojęcie mimikry kulturowej, do którego on nawiązuje, zostało stworzone, żeby zwrócić uwagę na fakt, iż podobnie jak w przyrodzie, także w relacjach międzyludzkich słabsze podmioty chciały (lub były zmuszone chcieć) upodobnić się do silniejszych czy — jak powiedziałby bułgarski historyk Alexander Kiossev - uważanych przez nie za swoisty wzór „normalności” (w rzeczywistości raczej jej oksymoron), w znaczeniu tego, co przez nie pożądane. Przyczyn, dla których słabsze podmioty sięgają po tę strategię, Kiossev upatruje w charakterystycznym według niego dla państw środkowoeuropejskich zjawisku „samokolonizujących się kultur”, które już u zarania rozpoznały własną niższość (żywiąc przekonanie, iż są europejskie, ale nie w pełni), w następstwie czego ukonstytuowały się jako kultury zależne (Kiossev 1999, 2008). Jednak warto odnotować, że chociaż z przytoczonych wypowiedzi zachodnich polityków przebija silny paternalizm, w ostatnich kilku latach podejście UE powoli zaczęło się zmieniać, czego przejawem jest podejmowanie prób zastępowania strategii wiernej kopii (carbon copy) przez strategię określoną przez Judith $\mathrm{Bu}-$ tler (2003) mianem „przekładu kulturowego” (przekładu między kulturami) (zob. Buden 2011). Charakterystyczne dla niej jest założenie, że wzajemna relacja powinna powodować zmiany u obu partnerów ${ }^{5}$, nie zmuszając słabszego z nich do uciekania się do „przebiegłej układności”, która sprawia, iż dzięki wprowadzanym reformom nie tyle stanie się on wierną kopią Zachodu, ile raczej drwiną z niego (Young 2012, s. 162; Bhabha 2010, s. 81).

\section{(DE)KONSTRUKCJA STEREOTYPÓW DOTYCZĄCYCH BAŁKANÓW W SZTUCE}

O strategii petryfikacji stereotypów dotyczących Bałkanów wspominałam już we fragmencie odnoszącym się do twórczości reżysera Emira Kusturicy. Podobnie żywotne są owe stereotypy w szeroko rozumianej muzyce popularnej, czego ciekawą analizę możemy przeczytać między innymi w opracowaniu Marina Cvitanovicia (2009, s. 317-335). Jednak z uwagi na ograniczenia miejsca, chciałabym się skupić na próbach dekonstrukcji obu stereotypów obecnych w sztuce współczesnej, czego dobrym przykładem są między innymi prace Vlado Marteka, Mariny Abramović czy Šelji Kamerić.

Jedną z pierwszych prób takiej dekonstrukcji była grafika Vlado Marteka zatytułowana Bałkany. Martek wpisał ów toponim w kontury narysowanej na czerwono mapy Stanów Zjednoczonych Ameryki, a nazwy głównych amerykańskich miast zastąpił nazwiskami chorwackich artystów. Jego praca została odebrana jako gra z polityczną poprawnością, zamazał w niej bowiem różnice mię-

5 Dobrym przykładem zmiany strategii w kierunku „przekładu między kulturami” są rozwijające się w ostatnim okresie programy wspierające dziedzictwo kulturowe (np. podtrzymywanie tradycji kulinarnych lub folkloru) państw członkowskich i ich regionów. 
dzy dwoma obszarami traktowanymi jako diametralnie różne: Ameryką, zwykle przedstawianą jako kolebka demokracji i przykład państwa, w którym od wieku możliwe jest pokojowe współżycie zróżnicowanego etnicznie i kulturowo społeczeństwa, oraz Bałkanami traktowanymi jako symbol etnicznej nietolerancji (zob. Kalčić, b.d.). Zresztą sam akt wprowadzenia przez artystę nowej nazwy ma ważne znaczenie, gdy według postkolonialistów „akt nazwania i zmiany nazw geograficznych stanowi akt władzy i zawłaszczenia" (Young 2012, s. 81).

Innym istotnym przykładem są dwie głośne prace Mariny Abramović: Balkan Baroque i Balkan Erotic Epic ${ }^{6}$. Pierwsza $z$ nich, w której Abramović odniosła się do toczących się $w$ latach dziewięćdziesiątych wojen związanych z rozpadem federalnego państwa, miała na celu dekonstrukcję stereotypu „Bałkanów drastycznych". Została ona wystawiona i nagrodzona na Biennale w Wenecji w 1997 roku. Warto wspomnieć, że po dość głośnym skandalu artystka ostatecznie zaprezentowała ją w pawilonie włoskim, a nie jugosłowiańskim (którego nazwa nota bene przetrwała dłużej niż państwo, którego twórczość winna w nim być reprezentowana) (Richards 2010, s. 102-103). W drugim projekcie Balkan Eriotic Epic (2004) artystka podjęła dialog ze stereotypem „Bałkanów magicznych".

Balkan Baroque składał się z tryptyku, tworzonego przez: wideoportrety rodziców Mariny Abramović (obok których ustawiono ledwo widoczne trzy miedziane naczynia pełne wody, symbolizujące oczyszczenie duchowe), krótkiego filmu wideo "Jak my na Bałkanach zabijamy szczury" (How we in the Balkans kill the rats) oraz performansu czyszczenia stosu 1500 wołowych kości, trwającego po 6 godzin dziennie przez 4 kolejne dni, w czasie którego artystka w śnieżnobiałej sukni szorowała je szczotką, siedząc na szczycie usypanej z nich góry i śpiewała przy tym (czasem melorecytując jak mantrę) pieśni zapamiętane z dzieciństwa, każdego dnia inną. W instalacji wideo, dotyczącej sposobów deratyzacji szczurów, Abramović wystąpiła w lekarskim fartuchu i mówiła po angielsku, z wyraźnym obcym akcentem, co jest symbolem podjęcia przez artystkę podwójnej gry $z$ odbiorcami i komunikowania się $z$ nimi zarówno z pozycji insajderki (używanie formy „my”), jak i outsiderki (użycie obcego języka, co w przekazach dotyczących Bałkanów uważane było za gwarancję jego obiektywizmu) (Luketić 2008a, s. 22). Zresztą zabieg ów można traktować zarówno jako próbę skomentowania przez Abramović własnej, dwoistej tożsamości (artystka od 1975 roku mieszka za granica), ale też nawiązanie do powstałej w 1994 roku pracy serbskiego konceptualisty - Mladena Stilinovicia, której przesłanie brzmiało: „Artysta, który nie mówi po angielsku, nie jest artystą" (An artist who cannot speak english is no artist). Jednak bezstronność wygłaszanego przez nią niezwykle monotonnym głosem miniwykładu

${ }^{6}$ Zdjęcia obu projektów można obejrzeć na stronie internetowej (http://www.artnet.com/use rnet/awc/awc_thumbnail.asp?aid $=424588417 \&$ gid $=424588417 \&$ works_of_art $=1 \&$ cid $=102125$ [29.09.2014]). 
podawało w wątpliwość konsekwentne używanie pierwszej osoby liczby mnogiej - my. W rzeczywistości zaś jej beznamiętna opowieść dotyczyła tego, jak szczury, a więc typowe istoty stadne i społeczne zmienić w śmiertelnie przerażone, zaszczute zwierzęta, a następnie przeistoczyć je w wilkołaki, które będą się wzajemnie mordować ${ }^{7}$. Jednym $z$ celów tego nagrania była dekonstrukcja popularnego wówczas stereotypu o rzekomej biologicznej skłonności „bałkańskich” narodów do przemocy. Pod koniec nagrania, usłyszawszy żywiołową muzykę, Abramović porzuca dotychczasową rolę quasi-obiektywną i quasi-naukowa, zrzuca lekarski fartuch (a tym samym dekonstruuje swoją zewnętrzną/obiektywną pozycję) i przeistacza się w stereotypową bałkańską kobietę, tyleż namiętną, co podatną na irracjonalne impulsy (w tym przypadku muzykę). Sam akt czyszczenia kości nawiązywał do czystek etnicznych oraz symbolizował rytuału swoistego katharsis z wojennych traum (Avgita 2012, s. 13, 22). Jak podkreśla Tanja Miletić-Oručević, owa góra kości piętrząca się dookoła artystki „semantycznie nawiązuje do bałkańskiej rzeźni, do toczącej się wojny, która rozpoczęła się od kości i na nich skończyła". Preludium do wojny stanowiły procesje ze szczątkami księcia Lazara Hrebeljanovicia oraz wykopywanie kości ofiar drugiej wojny światowej, a zakończenie masowe mogiły z tysiącami ofiar. Sama akt ich czyszczenia można również tłumaczyć jako próbę uwolnienia się raz na zawsze od ich symbolicznego ciężaru. Według Miletić-Oručević (2013, s. 132): „wyczyszczone kości miałyby przestać być krwawym mięsem i źródłem konfliktów, mogłyby wrócić do ziemi jako symbol ostatecznego "uspokojenia» historii".

Drugim ważnym performansem Abramović, tym razem stanowiącym komentarz do stereotypu „Bałkanów magicznych” (a raczej próbę jego dekonstrukcji), jest pochodząca z 2005 roku praca Balkan Erotic Epic. Składa się ona $z$ kilku krótkich filmów wideo, których tematem jest tradycyjna bałkańska magia płodności i związane $z$ nią rytuały. W filmach tych możemy obejrzeć między innymi kobiety masujące swoje piersi czy pokazujące chmurom łona, by odpędzić deszcz oraz mężczyzn odbywających stosunek z ziemią, co z kolei miało zapewnić urodzaj. Wykorzystanie motywów erotycznych miało niezwykle ważne znaczenie, $z$ reguły odgrywają one bowiem, jak podkreślał Piotr Piotrowski (2010, s. 198), ,istotną rolę w każdym procesie egzotyzowania odległych, niezachodnich regionów. [Erotyka] Stanowi część orientalizmu, zainteresowań Wschodem, stanowi też część bałkanizmu". Między kolejnymi sekwencjami filmu pojawia się również wideo podobne w zamierzeniach do instalacji "Jak my na Bałkanach zabijamy szczury". Tym razem Abramović odgrywa rolę profesorki prezentującej praktyki magii i płodności, które zostały spisane przez badaczy (etnologów i antropologów) prowadzących badania na Bałkanach. Komentując przedsięwzięcie Abramović zauważyła, że w bałkańskim folklorze płodność jest traktowana jako nadludzka siła, a poprzez erotykę człowiek próbuje

${ }^{7}$ Fragment transkrypcji tego tekstu można znaleźć w książce Mary Richards (2010, s. 104). 
uczynić się równym bogom. W nagraniach tych Bałkany jawią się jako miejsce swoistej „postmodernistycznej nostalgii”, a ich „zacofanie i zaściankowość zostały przedstawione jako alternatywa dla współczesnych «nadcywilizowanych» [over-civilised] społeczeństw, które utraciły kontakt z istotą życia" (Avgita 2012, s. 22-23). Warto jeszcze zwrócić uwagę, że ów performans ma także znacznie głębszy niż się z pozoru wydaje wymiar polityczny. Niezwykle trafna wydaje się w tym kontekście ocena Piotra Piotrowskiego (2010, s. 199), który stwierdził:

„[...] [Abramović nie kpi] z samej bałkańskiej kultury, ale z jej użycia. Ludowe stroje, ludowe mity, rzewne pieśni słowiańskie, słowem, narodowa tradycja często była i jest przywoływana przez nacjonalistycznych polityków i ich partie, a takich na Bałkanach nie brakuje. Pokazanie erotycznego wymiaru narodowej tradycji niejako rozbraja nacjonalistyczny dyskurs, ukazując go nie w świetle narodowej powagi, lecz w lekkiej konwencji rubasznej, ludowej przypowieści, odbierając tym samym politykom narzędzie nacjonalistycznej mobilizacji".

Ostatnią pracą, na którą chciałabym zwrócić uwagę, jest zrealizowany w 2003 roku głośny projekt Šejli Kamerić zatytułowany „Bośniacka Dziewczyna" (Bosnian Girl), w którym artystka próbowała udzielić odpowiedzi na pytanie o to, jaką rolę odgrywa autoreprezentacja $\mathrm{w}$ procesie konstruowania tożsamości. Praca tę stanowiło zdjęcie młodej kobiety (samej artystki), patrzącej w obiektyw, a u dołu zdjęcia został umieszczony napis: „Bez zębów?... Wąsy?... Śmierdzi? Dziewczyna z Bośni!” 8 , w rzeczywistości będący kopią graffiti umieszczonego przez nieznanego holenderskiego żołnierza (w latach 1992 -1995 wojska holenderskie należały do kontyngentu UNPROFOR w Bośni) na murze jednego $z$ sarajewskich budynków. Praca Kamerić została opublikowana w formie plakatów, pocztówek i ogłoszeń w czasopismach. Należy się zgodzić z Katarzyną Pabijanek, według której stanowiła ona doskonały komentarz do mechanizmu marginalizowania Bałkanów jako „Innego” Europy, a samo „graffiti wykorzystane przez Kamerić to mniej finezyjne wytłumaczenie mechanizmu konstruowania własnej indywidualnej lub zbiorowej tożsamości poprzez stygmatyzację inności" (Pabijanek 2010). Kamerić jest też autorką innej głośnej instalacji: „EU citizens/Others” (2000). Tworząc instalację, nawiązującą wyglądem do lotniskowych bramek, artystka chciała pokazać, iż mimo nagłaśnianego upadku granic w Europie, w rzeczywistości wcale one nie znikły, doszło jedynie do zastąpienia jednych granic innymi. Mieszkańcy kontynentu wciąż są podzielni na lepszych (obywateli UE) i gorszych (pozostałych).

Przedstawione tu przykłady obrazujące współczesne funkcjonowanie dwóch najbardziej rozpowszechnionych stereotypów dotyczących Bałkanów z pewno-

8 Prace artystki można obejrzeć na jej stronie internetowej (http://sejlakameric.com/works [29.09.2014]). 
ścią nie wyczerpują tematu, mają jedynie na celu zachęcenie do podjęcia dalszej dyskusji oraz stanowią apel o większy obiektywizm. W pełni podzielam opinię Marii Todorovej (2008, s. 403), która stwierdziła, iż Bałkany posłużyły „za magazyn cech negatywnych, w opozycji do których zbudowano pozytywny i pochlebny wizerunek „Europejczyka” i „Zachodu”. Na dokonaną w tym przypadku stygmatyzację możemy patrzyć jako na przejaw symbolicznej władzy Zachodu nad (szeroko rozumianym) Wschodem. Jednak pytanie, z którym chciałabym pozostawić czytelników, brzmi: czy więcej tego rodzaju działania mówią nam o Bałkanach czy może o podmiotach, które dokonują ich napiętnowania?

\section{BIBLIOGRAFIA}

Avgita Louise, 2007, The Balkans Does Not Exist, „Third Text”, t. 21, nr 2.

Avgita Louisa, 2012, Marina Abramović's Universe: Universalising the Particular in Balkan Epic, „Cultural Policy, Criticism and Management Research", t. 6 (htp://culturalpolicyjournal.wordpress. com/past-issues/issue-no-6/balkan-epic [29.09.2014]).

Balkanski..., 2009, Balkanski glas razuma (10): Mračno zrcalo Europe 10, „Slobodna Dalmacija”, 4 kwietnia (http://www.slobodnadalmacija.hr/Spektar/tabid/94/articleType/ArticleView/arti cleId/48959/Default.aspx [dostęp 19.03.2014]).

Bakić-Hayden Milica, 1995, Nesting Orientalisms: the Case of Former Yugoslavia, „Slavic Review”, t. 54, nr 4.

Bhabha Homi K., 2010, Miejsca kultury, tłum. T. Dobrogoszcz, WUJ, Kraków.

Bogusławska Magdalena, 2008, Jak leczyć migrenę, czyli o wizerunku Czarnogórców w polskim piśmiennictwie popularnym przełomu XIX $i$ XX wieku, w: Magdalena Bogusławska, Grażyna Szwat-Gyłybowa (red.), Bunt tradycji — tradycja buntu. Ksiega dedykowana Profesorowi Krzysztofowi Wroctawskiemu, Warszawa.

Buden Boris, 2011, What to Do with the Question: „What will Balkans look like in 2020?”, Vienna 2011.

Buden Boris, 2012, Strefa przejścia. O końcu postkomunizmu, tłum. Michał Sutowski, Wydawnictwo Krytyki Politycznej, Warszawa.

Butler Judith, 2003, Wywiad z prof. Judith Butler, przeprowadzony 22 marca 2003 r. w San Francisco, opublikowany w czasopiśmie „The Believer”; przedruk: „Nowa Krytyka. Czasopismo Filozoficzne" (http://www.nowakrytyka.pl/spip.php?article400 [25.09.2014]).

Cvitanović Marin, 2009, (Re)konstrukcija balkanskih identiteta kroz popularnu glazbu, „Migracijske i etničke teme", t. 25, nr 4.

Đerić Gordana, 2009, Stereotip i studije o Balkanu, „Antropologija”, nr 9.

Fiske Susan T., Taylor Shelley E., 1984, Social Cognition, Sage, New York.

Glenny Misha, 2012, The Balkans: Nationalism, War and the Great Powers, 1804-1999, Granta, London. Goldsworthy Vesna, 2003, Invencija i in(ter)vencija: retorika balkanizacije, „Sarajevske sveske”, nr 2.

Holbrooke Richard, 1999, To End a War, Random House, New York.

Iordanova Dina, 1996, Conceptualizing the Balkans in Film, „Slavic Review”, t. 55, nr 4.

Iordanova Dina, 2010, Cinema of Flames. Balkan Film, Culture and the Media, British Film Institute, London.

Jansen Stef, 2001, Svakodnevni orijentalizam: doživljaj „Balkana”/„Evrope” u Beogradu i Zagrebu, „Filozofija i društvo", t. 18.

Jezernik Božidar, 2007, Dzika Europa. Bałkany w oczach zachodnich podróżników, tłum. Piotr Oczko, Universitas, Kraków.

Judt Tony, 2012, Wielkie złudzenie? Esej o Europie, tłum. Andrzej Jankowski, Rebis, Poznań.

Kalčić Silva, b.d., Vlado Martek. „Inter(aktiv) radionice sa umjetnicima” (http://www.andreja.org/ interaktiv/martek.htm [29.09.2014]). 
Kaplan Robert, 2010, Bałkańskie upiory. Podróż przez historię, tłum. J. Ruszkowski, Czarne, Wołowiec. Kiossev Alexander, 1999, Notes on the Self-colonising Cultures, w: Bojana Pejić, David Eliot (red.), After the Wall. Art and Culture in Post-Communist Europe, Moderna Museet, Stokholm (www.kultura.bg/media/my_html/biblioteka/bgvntgrd/e_ak.html [15.09.2014]).

Kiossev Alexander, 2008, The oxymoron of normality, „Eurozine”, 1 kwietnia (http://www.eurozine. com/articles/2008-01-04-kiossev-en.html [15.09.2014]).

Kršić Dejan, 2003, Umjetnost, tržište i evropske integracije: U gudurama Kassela 23Stu03, (www.dejankr sic.wordpress.com/2003/11/23/umjetnost-trziste-i-evropske-integracije-u-gudurama-kassela [15.09.2014]).

Lovrić Jelena, 2008, Mirin ples vampira, „Jutarnji list”, 11 listopada (http://www.jutarnji.hr/mirin-pl es-vampira/193496/ [30.05.2014]).

Luketić Katarina, 2008a, Bijeg s Balkana. Balkan — imaginariji, mitovi, stvarnost, „Zarez”, 7 lutego.

Luketić Katarina, 2008b, Glad za autentičnom komunikacijom. Elizabeta Šeleva - intervju, „Zarez”, 7 lutego.

Luketić Katarina, 2013, Balkan — od geografije do fantazije, Algoritam Multimedia, Zagreb.

Maalouf Amin, 2002, Zabójcze tożsamości, tłum. Halina Lisowska-Chehab, PIW, Warszawa.

Markowska Joanna, 2010, Batkany - określenie medialne czy region geograficzny?, „Prace i Studia Geograficzne", t. 44.

Matošević Andrea, 2011, (Auto)egzotizacija Balkana i etnografija nositelja značenja u tri primjera sedme umjetnosti, „Narodna umjetnost”, t. 48, nr 2.

Milardović Anđelko, 2000, Hrvatska u „trećoj Europskoj ligi, „Dom i svijet. Informativni tjedni prilog za iseljenike", 30 października (www.hic.hr/dom/316/dom05.htm [20.05.2014]).

Miletić-Oručević Tanja, 2013, Marina Abramović. Ciało historyczne a ciato indywidualne, w: Magdalena Sztandara, Gotran Injac, Waldemar Kuligowski (red.). Bałkany performatywne. Rytuat — dramat — sztuka w przestrzeni publicznej, Wydawnictwo Uniwersytetu Opolskiego, Opole.

Montesquieu Charles Louis De Secondat, 1979, Listy perskie, tłum. Tadeusz Żeleński (Boy), Czytelnik, Warszawa.

Oczko Piotr, 2007, Od tłumacza, w: Božidar Jezernik., Dzika Europa. Batkany w oczach zachodnich podróżników, tłum. Piotr Oczko, Universitas, Kraków.

Pabijanek Katarzyna, 2010, Czy artystka, która nie mówi po angielsku, nie jest artystką? 23 sierpnia (www.obieg.pl [29.05.2014]).

Petrović Tanja, 2012, Yuropa. Jugoslovensko nasleđe i politike budućnosti u postjugoslovenskim društvima, Fabrika knjiga, Beograd.

Piber-Dąbrowska Kinga, Sędek Grzegorz, 2006, Spostrzeganie bez uprzedzeń i stereotypów, „Psychologia Społeczna", t. 2, nr 2.

Piotrowski Piotr, 2010, Agorafilia. Sztuka i demokracja w postkomunistycznej Europie, Rebis, Warszawa 2010.

Plassnik..., 2008, Plassnik: 2008 will be a decisive year for Croatia's path to joining the EU, 25 marca (http://www.bmeia.gv.at/en/the-ministry/press/announcements/2008/plassnik-2008-will-b e-a-decisive-year-for-croatias-path-to-joining-the-eu [01.06.2014]).

Richards Mary Elizabeth, 2010, Marina Abramović. Routledge Performance Practicioners, Routledge, London-New York.

Rihtman-Auguštin Dunja, 1997, Zašto i otkad se grozimo Balkana, „Erasmus: časopis za kulturu demokracije", nr 19.

Said Edward, 1991, Orientalizm, tłum. Witold Kalinowski, PIW, Warszawa.

Sanader..., 2009, Sanader pozvao Sloveniju da deblokira hrvatske pregovore sa EU, „Jutarnji list”, 31 marca (http://www.jutarnji.hr/sanader-pozvao-sloveniju-da-deblokira-hrvatske-pregovore -s-eu-om/200370 [30.05.2014]).

Škrabec Simona, 2013, Geografia wyobrażona. Koncepcja Europy Środkowej w XX wieku, tłum. Rozalya Sasor, MCK. Kraków. 
Slukan-Altić Mirela, 2011, Hrvatska kao Zapadni Balkan — geografska stvarnost ili nemetnuti identitet, „Društvena istraživanja”, t. 20, nr 2.

Spivak Chakravorty Gayatri, 1988, Can the Subaltern Speak, w: Cary Nelson, Lawrence Grossberg (red.), Marxism and the Interpretation of Culture, MacMillan, London.

Svilar Predrag, 2010, „Zapadni Balkan” - politički kontekst i medijska upotreba, „Socijološki pregled”, t. XLIV, nr 4.

Szczerek Ziemowit, 2013, Przyjdzie Mordor i nas zje, czyli tajna historia Stowian, Haart!, Kraków.

Todorova Maria, 2008, Batkany wyobrażone, tłum. Piotr Szymon, Magdalena Budzińska, Czarne, Wołowiec.

Ugrešić Dubravka, 2008, Nikogo nie ma w domu, tłum. Dorota Jovanka Ćirlić, Znak, Kraków.

Velikonja Mitja, 2007, Evroza. Kritika novog evrocentrizma, Biblioteka XX vek, Beograd.

Wallerstein Imannuel, 2007, Europejski uniwersalizm. Retoryka władzy, tłum. Adam Ostolski, Scholar, Warszawa.

Young Robert J.C., 2012, Postkolonializm. Wprowadzenie, tłum. Marek Król, Wydawnictwo UJ, Kraków.

Žižek Slavoj, 1999, You May!, „London Review of Books”, t. 21, nr 6 (http://www.lrb.co.uk/v21/ n06/slavoj-zizek/you-may [30.03.2014]).

Žižek Slavoj, 2009a, Przeciw prawom człowieka, w: Žižek. Przewodnik Krytyki Politycznej, Krytyka Polityczna, Warszawa.

Žižek Slavoj, 2009b, Zawsze stoje po jakiejś stronie, w: Žižek. Przewodnik Krytyki Politycznej, Krytyka Polityczna, Warszawa.

Živković Marko, 2012, Srpski sanovnik. Nacionalni imaginarijum u vreme Miloševića, Biblioteka XX vek, Beograd.

\section{SINCE THE BALKANS EXIST, BETTER NOT INVENT THEM-BETWEEN DESIRE FOR ESCAPE TO 'EU-ROPE' AND THE 'BALKANIZATION OF THE BALKANS'}

\section{Summary}

Vesna Goldsworthy once stated that interest in the Balkans lasts as long as there are conflicts in the area. Furthermore, that interest is extremely superficial. Europeans prefer to fit inhabitants of the Balkans into lasting 'popular' stereotypes (clichés) rather than to become acquainted with them. On the one hand, the Balkan region is viewed as being the proverbial powder keg, an area suffering from the 'eternal' hatred of the nations inhabiting it and stained with the blood of their fratricidal strife; at the very least the region is a synonym of extreme retrogression and obscurantism, from which only European paternalism can save it. On the other hand-the brighter picture-the region is viewed almost like a ludic open-air folk museum, as in the films of Emir Kusturica. Those who are more inclined to hold the first view dream of the Balkans' escape to 'EU-rope'; the latter do not in principle oppose remaining in this idyllic land 'flowing with rakia'. The aim of the article is to analyze the discourse concerning the Balkans in two dimensions of social life-politics and art.

\section{Key words / słowa kluczowe}

Balkans / Bałkany; stereotypes of the Balkans / stereotypy dotyczące Bałkanów; postcolonial studies / studia postkolonialne; Balkans in the political discourse / Bałkany w dyskursie politycznym; Balkans in art / Bałkany w sztuce 